U.S. Geological Survey Groundwater Resources Program

Groundwater Conditions During 2009 and Changes in Groundwater Levels from 1984 to 2009, Columbia Plateau Regional Aquifer System, Washington, Oregon, and Idaho

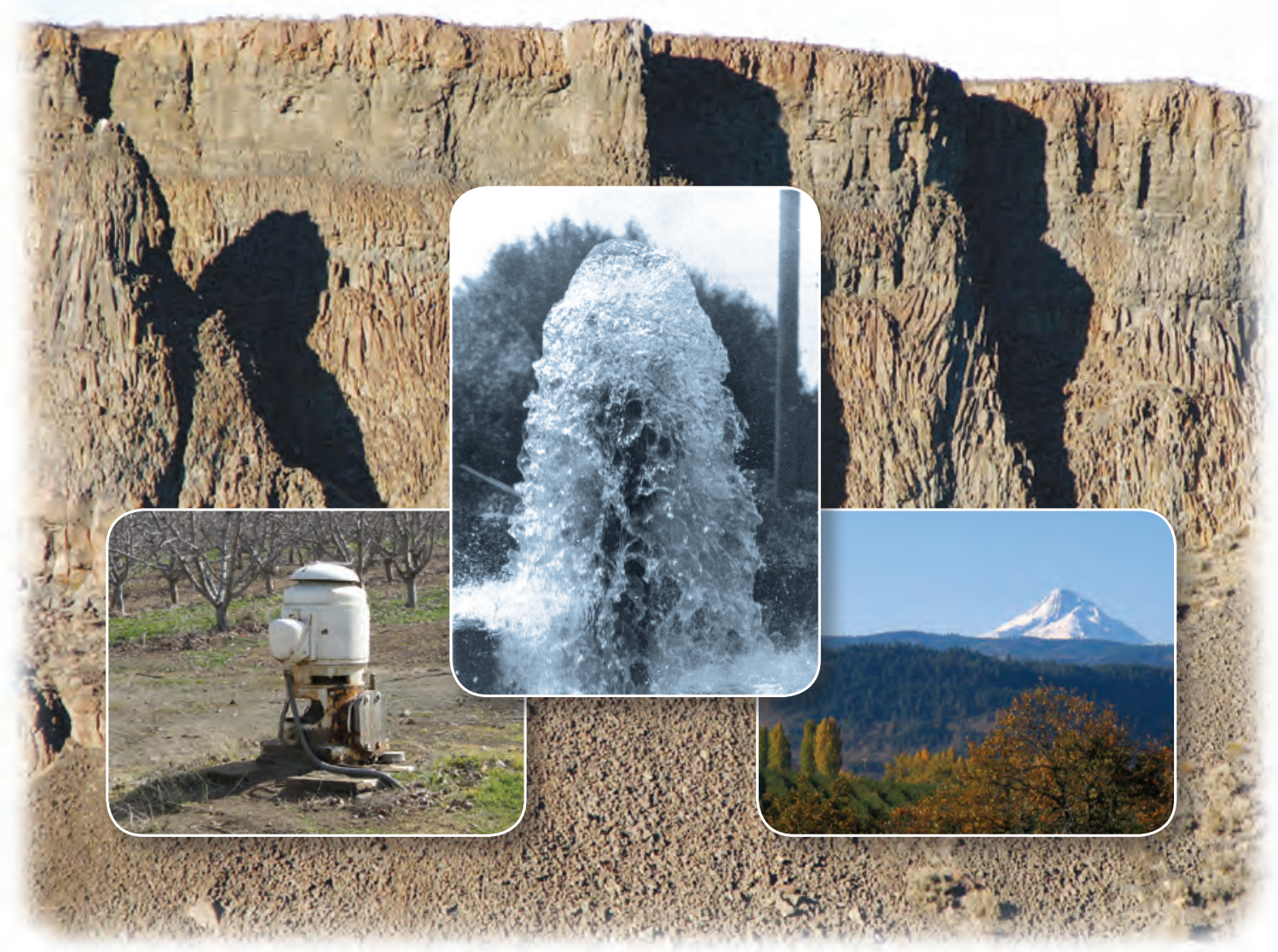

Scientific Investigations Report 2010-5040 
Cover: Lower left: Photograph of irrigation well in the vicinity of Toppenish, Washington. (Photograph taken by Karen Payne, U.S. Geological Survey, 2009.)

Center foreground: Photograph of "Pullman's Great Artesian Well," in the vicinity of Pullman, Washington. (Image by Artopho Studios, circa 1910, courtesy of Manuscripts, Archives, and Special Collections, Washington State University Libraries, PC2-10-44. Used with permission.)

Lower right: Photograph of vicinity of Mosier, Oregon with Mt. Hood in the distance. (Photograph taken by Jonathan Haynes, U.S. Geological Survey, 2007.)

Background: Photograph of Frenchman's Coulee in the vicinity of Quincy, Washington. (Photograph taken by Peter Prehn, private citizen, 2008. Used with permission.) 


\section{Groundwater Conditions During 2009 and Changes in Groundwater Levels from 1984 to 2009, Columbia Plateau Regional Aquifer System, Washington, Oregon, and Idaho}

By Daniel T. Snyder and Jonathan V. Haynes

U.S. Geological Survey Groundwater Resources Program

Scientific Investigations Report 2010-5040 


\section{U.S. Department of the Interior \\ KEN SALAZAR, Secretary}

\section{U.S. Geological Survey \\ Marcia K. McNutt, Director}

\section{U.S. Geological Survey, Reston, Virginia: 2010}

For more information on the USGS - the Federal source for science about the Earth, its natural and living resources, natural hazards, and the environment, visit http://www.usgs.gov or call 1-888-ASK-USGS

For an overview of USGS information products, including maps, imagery, and publications, visit http://www.usgs.gov/pubprod

To order this and other USGS information products, visit http://store.usgs.gov

Any use of trade, product, or firm names is for descriptive purposes only and does not imply endorsement by the U.S. Government.

Although this report is in the public domain, permission must be secured from the individual copyright owners to reproduce any copyrighted materials contained within this report.

Suggested citation:

Snyder, D.T., and Haynes, J.V., 2010, Groundwater conditions during 2009 and changes in groundwater levels from 1984 to 2009, Columbia Plateau Regional Aquifer System, Washington, Oregon, and Idaho: U.S. Geological Survey Scientific Investigations Report 2010-5040, 12 p., http://pubs.usgs.gov/sir/2010/5040/ 


\section{Contents}

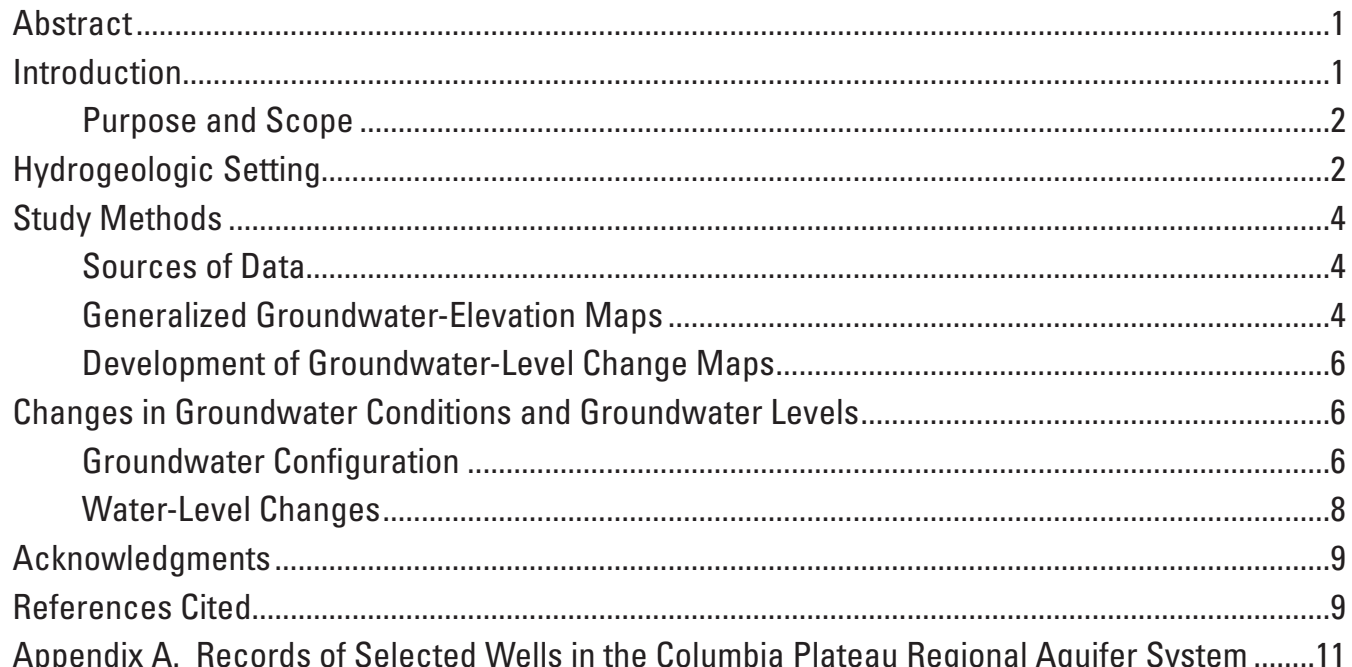

\section{Plates}

Plate 1. Structural Regions of the Columbia Plateau Regional Aquifer System, Washington, Oregon, and Idaho

Plate 2. Locations of wells and estimated groundwater levels for the Overburden unit, Columbia Plateau Regional Aquifer System, Washington, Oregon, and Idaho, spring 2009

Plate 3. Locations of wells and estimated groundwater levels for the Saddle Mountains unit, Columbia Plateau Regional Aquifer System, Washington, Oregon, and Idaho, spring 2009

Plate 4. Locations of wells and estimated groundwater levels for the Wanapum unit, Columbia Plateau Regional Aquifer System, Washington, Oregon, and Idaho, spring 2009

Plate 5. Locations of wells and estimated groundwater levels for the Grande Ronde unit, Columbia Plateau Regional Aquifer System, Washington, Oregon, and Idaho, spring 2009

Plate 6. Groundwater-level changes for the Overburden unit, Columbia Plateau Regional Aquifer System, Washington, Oregon, and Idaho, spring 1984 to spring 2009

Plate 7. Groundwater-level changes for the Saddle Mountains unit, Columbia Plateau Regional Aquifer System, Washington, Oregon, and Idaho, spring 1984 to spring 2009

Plate 8. Groundwater-level changes for the Wanapum unit, Columbia Plateau Regional Aquifer System, Washington, Oregon, and Idaho, spring 1984 to spring 2009

Plate 9. Groundwater-level changes for the Grande Ronde unit, Columbia Plateau Regional Aquifer System, Washington, Oregon, and Idaho, spring 1984 to spring 2009

\section{Figures}

Figure 1. Map showing long-term water level changes in selected wells, Columbia Plateau Regional Aquifer System, Washington, Oregon, and Idaho 


\section{Tables}

Table 1. Change in groundwater levels in wells in the Columbia Plateau Regional Aquifer System, Washington, Oregon, and Idaho, from spring 1984 to spring 2009

\section{Conversion Factors and Datums}

\begin{tabular}{lll}
\hline \multicolumn{1}{r}{ Multiply } & \multicolumn{1}{c}{ By } & \multicolumn{1}{c}{ To obtain } \\
\hline foot (ft) & 0.3048 & meter $(\mathrm{m})$ \\
foot per year (ft/yr) & 0.3048 & meter per year $(\mathrm{m} / \mathrm{yr})$ \\
meter $(\mathrm{m})$ & 3.281 & foot $(\mathrm{ft})$ \\
mile (mi) & 1.609 & kilometer $(\mathrm{km})$ \\
square mile $\left(\mathrm{mi}^{2}\right)$ & 2.590 & square kilometer $\left(\mathrm{km}^{2}\right)$ \\
\hline
\end{tabular}

\section{Datums}

Vertical coordinate information is referenced to the North American Vertical Datum of 1988 (NAVD 88). Vertical coordinate information for historical data collected and stored as National Geodetic Vertical Datum of 1929 (NGVD 29) has been converted to NAVD 88 for this publication. Conversion between NAVD 88 and the commonly used NGVD 29 varies spatially; however, over most of the study area the following conversion can be used:

NGVD 29 = NAVD $88-3.6$ feet.

This conversion generally is accurate within about \pm 0.5 feet for 95 percent of the study area. The reader is directed to either the National Geodetic Survey Web site for VERTCON at http:/l www.ngs.noaa.gov/TOOLS/Vertcon/vertcon.html or the U.S. Army Corps of Engineers Web site for Corpscon at http://crunch.tec.army.mil/software/corpscon/corpscon.html for more accurate conversions.

Horizontal coordinate information is referenced to the North American Datum of 1983 (NAD 83). Horizontal coordinate information for historical data collected and stored as North American Datum of 1927 (NAD 27) has been converted to NAD 83 for this publication. Conversion between NAD 83 and the commonly used NAD 27 varies spatially, and the difference in lateral positions can be greater than 300 feet. For assistance with conversions, the reader is directed to either the National Geodetic Survey Web site for NADCON at http://www.ngs.noaa.gov/TOOLS/ Nadcon/Nadcon.html or the U.S. Army Corps of Engineers Web site for Corpscon at http:// crunch.tec.army.mil/software/corpscon/corpscon.html.

Elevation, as used in this report, refers to distance above the vertical datum. 


\title{
Groundwater Conditions During 2009 and Changes in Groundwater Levels from 1984 to 2009, Columbia Plateau Regional Aquifer System, Washington, Oregon, and Idaho
}

\author{
By Daniel T. Snyder and Jonathan V. Haynes
}

\begin{abstract}
Groundwater elevations in three basalt units and one unconsolidated hydrogeologic unit in the Columbia Plateau Regional Aquifer System were measured and evaluated to provide a regional overview of groundwater conditions in spring 2009. Water levels for the Saddle Mountains unit, the Wanapum unit, the Grande Ronde unit, and for the overlying Overburden unit were measured in 1,752 wells during spring 2009 by the U.S. Geological Survey (USGS) and 10 other Federal, State, Tribal, and local agencies, including 66 wells located and measured by the USGS specifically for this study. These data were analyzed to determine the presence of spatial correlation of groundwater levels with distance and direction from each other. Groundwater flow in the Palouse Slope structural region showed evidence of being more continuous relative to groundwater flow in the Yakima Fold Belt, where the geologic complexity may contribute to compartmentalization of groundwater flow. This information was used to interpolate the generalized groundwater elevations for each of the basalt hydrogeologic units and to provide information on regional flow.

Water-level change maps were constructed for the three basalt hydrogeologic units and the Overburden (unconsolidated) unit. Groundwater levels measured in spring 1984 and 2009 in 470 wells were compared. Small to moderate groundwater-level declines were measured in most wells, although declines greater than $100 \mathrm{ft}$ and as great as $300 \mathrm{ft}$ were measured in many wells. Essentially unchanged groundwater levels were measured in other wells. Of the wells measured in 1984 and 2009, water levels declined in 83 percent of the wells, and declines greater than $25 \mathrm{ft}$ were measured in 29 percent of all wells. The groundwater-level changes were greatest in the deeper hydrogeologic units. Mean groundwater-level changes ranged from a $7 \mathrm{ft}$ decline for the Overburden unit to a $51 \mathrm{ft}$ decline for the Grande Ronde unit. The average annual rates of groundwater-level change for the 25-year period ranged from a $0.3 \mathrm{ft} / \mathrm{yr}$ decline for the Overburden unit to a $2.0 \mathrm{ft} / \mathrm{yr}$ decline for the Grande Ronde unit.
\end{abstract}

\begin{abstract}
Groundwater level declines were identified throughout the Columbia Plateau, but areas with large and widespread declines were located in the central northern part of the study area, in parts of the Yakima River basin in Washington, in the Pullman-Moscow area in Washington and Idaho, and in parts of the Umatilla River basin in Oregon. These declines are in areas known to rely heavily on groundwater for irrigation and other uses.
\end{abstract}

\section{Introduction}

The Columbia Plateau Regional Aquifer System (CPRAS) covers about 44,000 $\mathrm{mi}^{2}$ within the Columbia River basin in southeastern Washington, northeastern Oregon, and western Idaho (pl. 1). The population of the region is more than 1.3 million people (2000 census) and important agricultural industry has developed despite its arid to semi-arid climate and limited access to surface-water resources. Groundwater availability in the aquifers of the area is therefore a critical water-resource management issue because the water demand for agriculture, economic development, and ecological needs is high.

The primary aquifers of the CPRAS are basalts of the Columbia River Basalt Group and the overburden, consisting of overlying basin-fill sediments. Groundwater availability issues in the basin include (1) widespread water-level declines associated with development of groundwater resources for irrigation and other uses, (2) reduction in base flow to rivers and associated effects on stream temperature and water quality, and (3) current and anticipated effects of global climate change on recharge, base flow, and, ultimately, groundwater availability.

The U.S. Geological Survey (USGS) Groundwater Resources Program began a study of the CPRAS in 2007 with the broad goals of characterizing the hydrologic status of the system, identifying trends in groundwater storage and use, and quantifying groundwater availability (U.S. Geological Survey, 2008). The study approach includes documenting changes in the status of the system, quantifying the hydrologic budget for 
the system, updating the regional hydrogeologic framework, and developing a groundwater-flow simulation model for the system. The simulation model will be used to evaluate and test the conceptual model of the system and later to evaluate groundwater availability under alternative development and climate scenarios.

\section{Purpose and Scope}

The scope and objectives of this report are to characterize current (2009) groundwater conditions within each of the primary basalt aquifers and to evaluate changes in groundwater levels since the last regional synoptic measurement in 1984 (Whiteman, 1986; Vaccaro, 1999) through the presentation of maps of groundwater elevation and water-level change for the hydrogeologic units in the CPRAS. Regional assessment of water-level data from the CPRAS is necessary to document regional water-level conditions and to develop a broad view of the effects of groundwater development and management in the sustainability and availability of water supply in the region. This information is useful to delineate areas of water-level changes due to withdrawals, irrigation recharge, or climate and to identify areas with substantial data gaps that may preclude effective management of groundwater resources.

\section{Hydrogeologic Setting}

Overviews of the geology and hydrology of the Columbia Plateau presented in this section summarize detailed descriptions in reports that describe the groundwater flow system, including its boundaries, hydraulic characteristics, and components of recharge and discharge (Vaccaro, 1999); discuss the hydrology based on numerical modeling (Bauer and Hansen, 2000); and discuss the thickness, extent, and lithology of hydrogeologic units within the CPRAS (Kahle and others, 2009).

The Columbia Plateau is an intermontane basin between the Rocky Mountains and the Cascade Range filled mostly with Cenozoic basalt and sediment. The Columbia River Basalt Group consists of a series of basalt flows that erupted during various stages of the Miocene Age, 17 million to 6 million years ago. More than 300 flows have been identified and individual flows range in thickness from $10 \mathrm{ft}$ to more than $300 \mathrm{ft}$ (Tolan and others, 1989; Drost and others, 1990). Soils derived from flows or sediments deposited on the surface of a flow were sometimes preserved, creating sedimentary interbeds between flows. The CPRAS occurs in an area of several structural regions (pl. 1). The geologic properties of these structural regions may influence groundwater flow through compartmentalization (the creation of distinct zones within an aquifer with limited interconnectivity) of the hydrogeologic units. The presence and importance of compartments in the CPRAS has been recognized and discussed in numerous studies (for example Newcomb, 1959; Porcello and others, 2009). Groundwater-level data analyzed for this study, however, were insufficient to evaluate compartmentalization fully.

The largest structural regions in the CPRAS consist of the Yakima Fold Belt and the Palouse Slope, which occupy the Columbia River basin. The Yakima Fold Belt includes the western and central parts of the Columbia River basin and consists of a series of anticlinal ridges and synclinal valleys trending roughly east-west (Reidel and others, 2002). Folds and faults within this region affect groundwater movement by offsetting or altering permeable interflow zones to create effective barriers to flow (Drost and others, 1990; Reidel and others, 2002). The Palouse Slope in the eastern part of the basin is much less deformed and has a gently southwestward dipping slope. The other structural regions within the CPRAS are the Blue Mountains, a composite anticlinal structure that forms the southeastern extent of the Columbia River basin, and the Clearwater Embayment, which marks the eastward extent of the CPRAS along the foothills of the Rocky Mountains.

Generalized hydrogeologic units recognized in this investigation, listed in order of generally increasing age, include Overburden, Saddle Mountains, Wanapum, and Grande Ronde. The hydrogeology was simplified by grouping the Mabton and Vantage Interbeds into the Saddle Mountains and Wanapum units, respectively. The Overburden unit consists predominantly of undivided, unconsolidated to semi-consolidated sedimentary deposits ranging from Miocene to Holocene in age (Drost and others, 1990). These include many types of deposits of local and (or) regional extent including fluvial, glaciofluvial, eolian, and volcanoclastic deposits that can range in thickness from 0 to 1,300 ft. The Saddle Mountains hydrogeologic unit consists mostly of the Saddle Mountains Basalt and interbed members and is the least extensive and youngest formation of the Columbia River Basalt Group. Most of the unit is in the west-central part of the study area, with less continuous occurrences in the Blue Mountains and eastward into Idaho. Thickness of the Saddle Mountains unit can range from 0 to about 1,000 ft. The Wanapum hydrogeologic unit, composed mostly of basalt and interbed members of the Wanapum Basalt, is in the northcentral part of the study area. Much of the unit lies beneath the Overburden and Saddle Mountains units. Thickness of the Wanapum unit ranges from 0 to about 1,200 ft. The Grande Ronde hydrogeologic unit is the oldest and most extensive of the basalt units. This unit underlies most of the study area, except for an area along the southern boundary of the CPRAS in Oregon and along the eastern edge of the aquifer system in Idaho. The Grande Ronde unit contains the basalt and interbed members associated with the Grande Ronde Basalt. Thickness of the unit is largely unknown, but may be greater than $15,000 \mathrm{ft}$ near the central part of the basin (Reidel and others, 2002). 
Seasonal fluctuations of groundwater levels, due to recharge from precipitation, irrigation, or canals, or due to discharge to rivers or wells, are typical in the surficial or shallow aquifers of the CPRAS, although this also has been observed in deeper, non-surficial units. Long-term groundwater levels in the CPRAS, however, have been undergoing substantial changes since the 1930s (ig. 1).

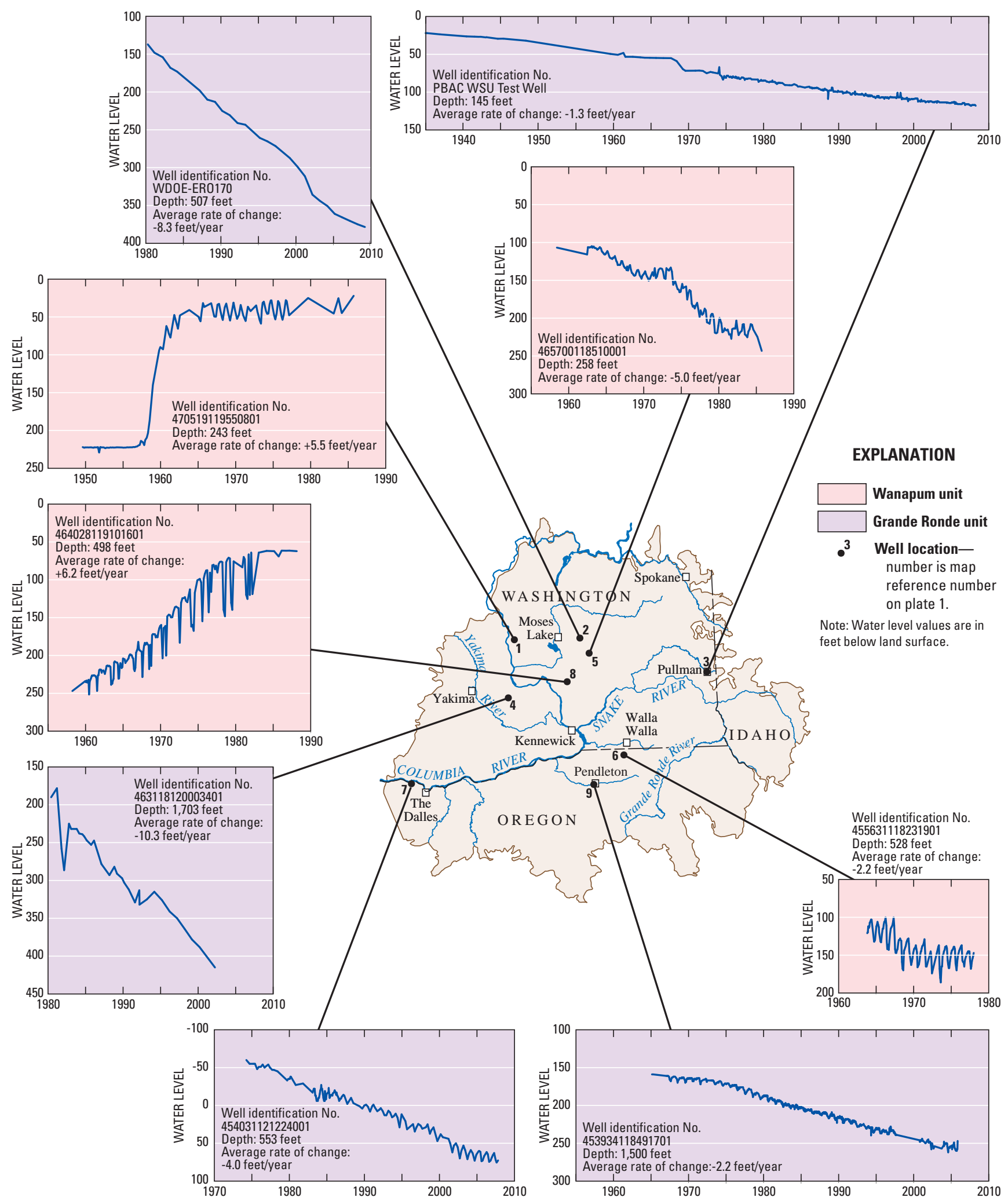

Figure 1. Long-term water level changes in selected wells, Columbia Plateau Regional Aquifer System, Washington, Oregon, and Idaho. All hydrographs are at same scale. 
Groundwater level declines due to pumping have caused many wells to go dry, which required deepening of these wells to remain productive. Rises in groundwater due to recharge from canals and irrigation have created concerns of potential water logging of crops. Continued monitoring is needed to further evaluate human- or climate-induced changes to the groundwater system.

\section{Study Methods}

The method of analysis used to evaluate the configuration (shape or form) of the current (2009) groundwater surface in the CPRAS units relied on water-level data from wells measured in spring 2009. These data were used with statistical methods to determine the presence of spatial correlation of groundwater levels with distance and direction from each other. This information was used to interpolate the groundwater elevations between observations for each hydrogeologic unit. The change in groundwater levels between 1984 and 2009 was determined by computing the change in water-level elevations from wells with observations in 1984 and 2009, and analyzing these changes for spatial patterns to aid in interpolation.

\section{Sources of Data}

The spring 2009 groundwater-levels for the CPRAS were synoptic (collected simultaneously) sets of measurements of the depth to water in wells representative of a single hydrogeologic unit as part of routine monitoring. In addition to the water levels measured by the USGS, data were provided by the U.S. Department of Energy, Oregon Water Resources Department, Confederated Tribes of the Umatilla Indian Reservation, Washington Department of Ecology, South Columbia Basin Irrigation District, Walla Walla Basin Watershed Council, Palouse Basin Aquifer Committee, East Columbia Basin Irrigation District, and Bureau of Reclamation. These agencies provided well information and water-level data collected during late winter and early spring 2009, prior to the typical start of significant pumping for agriculture. The spatial distribution of the wells measured in the existing monitoring networks was analyzed and determined to be insufficient for understanding groundwater levels in large areas of each of the hydrogeologic units. Therefore, the monitoring network data were supplemented with measurements from wells specifically selected for this study. Wells were selected from those measured during the 1984 USGS synoptic water-level investigation (Vaccaro, 1999) on the basis of the primary hydrogeologic unit to which the wells were open (a screened or open part of the well through which water enters-referred to as the open interval) and their proximity to areas of sparse data for the corresponding hydrogeologic unit. Priority was given to wells with water-level measurements from spring 1984 to facilitate the comparison of water levels between 1984 and 2009. Sixty-six of these supplemental wells that fit these selection criteria were identified and located, and water levels were measured in early spring 2009 by the USGS (pls. 2, 3, 4, and 5; appendix A). The number of wells measured during spring 2009 from all sources totaled 1,752 and were apportioned between the hydrogeologic units as follows: Overburden, 984 wells; Saddle Mountains, 118 wells; Wanapum, 288 wells; and Grande Ronde, 362 wells.

The water-level change analysis evaluated water-level data from spring 1984 obtained from the USGS and eight other agencies. Of the 1,752 wells measured in spring 2009, corresponding water levels had been measured in 470 wells in spring 1984. The 1984 water-level measurements were apportioned between the hydrogeologic units as follows: Overburden, 197 wells; Saddle Mountains, 50 wells; Wanapum, 87 wells; and Grande Ronde, 136 wells (pls. 6, 7, 8, and 9; appendix A).

Information on land-surface elevation was needed to determine groundwater elevation from depth-to-water information. Land-surface elevations for many wells were provided by the agencies that measured the well. For the remaining wells, land-surface elevations were estimated as the median land-surface elevation using a 10-m lateral resolution Digital Elevation Model (DEM) (U.S. Geological Survey, 1999) within a $100-\mathrm{ft}$ radius of the reported location of the well to account for uncertainty with regard to the exact location of wells used in the study (appendix A).

The hydrogeologic units to which the wells were open were determined on the basis of assignments made by the agencies that provided the well data. For wells with no assigned hydrogeologic unit, open-interval information was compared with estimated unit-top elevations from a three-dimensional hydrogeologic framework model (E.R. Burns, U.S. Geological Survey, written commun., 2009) and was assigned to a specific unit if that unit comprised 75 percent or greater of the open interval (appendix A). If no units comprised 75 percent or greater of the open interval (multi-unit) or if information was insufficient to determine the hydrogeologic unit (unit unknown) then the water level from the well was excluded from all analyses.

\section{Generalized Groundwater-Elevation Maps}

Generalized groundwater-elevation maps for the three basalt hydrogeologic units were developed from the 2009 water-level data using a three-stage geostatistical process (Bossong and others, 1999, p. 25-29; Davis, 2002, p. 258-259). A similar map for the Overburden unit was not developed because the 2009 data density was insufficient to develop reliable surfaces of groundwater elevation for the 
isolated and discontinuous areas over which thick overburden deposits generally occur. The first stage of the process involved estimating the regional groundwater-elevation trend for each unit for the entire CPRAS extent using a regression-smoothing technique called locally weighted scatterplot smoothing (LOESS). The groundwater elevation estimated using the regional trend surface at the location of each well was subtracted from the groundwater elevation measured at the well. The surface represented by the residuals (remainders) is the configuration of the groundwater surface without the regional influence. The second stage consisted of variography (analysis of the correlation of measurements with distance and direction) using the groundwaterelevation residuals within defined structural regions for each hydrogeologic unit to determine trends in the groundwater surface due to the hydrogeologic conditions within the regions. The third stage was the interpolation of the groundwaterelevation residuals for each hydrogeologic unit using kriging (a statistical method of data analysis and interpolation), with the required kriging parameters determined by the variography analysis.

The advantage of kriging, variography, and regional trend removal is that smaller scale structure of the data is revealed and preserved in areas where data are sufficiently dense, whereas the regional trend provides an indication of the general tendency of groundwater elevation and flow direction in areas where data are sparse or nonexistent. Because the 2009 water-level data were relatively sparse in many parts of the CPRAS, only the generalized configurations of the groundwater surfaces for the basalt units could be reliably determined for the entire study area. These generalized water-level configurations are shown on plates $3-5$ using color shading rather than elevation contours to indicate that the maps are simplifications of the large and complex actual flow system. Generalized directions of groundwater flow derived from this analysis and depicted on maps were modified on the basis of detailed maps of regional and subregional groundwater levels that better illustrate groundwater flow directions that are available for many parts of the CPRAS (Whiteman, 1986; Whiteman and others, 1994; Vaccaro, 1999; and Vaccaro and others, 2009).

Because the CPRAS includes several distinctive structural regions (pl. 1) with markedly different densities of folds and faults that may be impediments to groundwater flow, an analysis was done to determine whether the spatial correlation between groundwater levels differed within these structural units for each hydrogeologic unit. This process included variography, which provides statistical measures of the degree of correlation between a groundwater measurement and other groundwater measurements based on the distance and direction that separates them. Typically, wells that are closer together in the same aquifer have similar water levels and respond similarly to stresses. As distance between wells increases, however, the similarity of measured values generally decreases. On the other hand, if a flow barrier exists between two closely spaced wells due to folds, faults, or changes in lithology that affect the hydraulic properties of the aquifers, then the hydraulic response to a given stress may be different in each well. The presence of a large number of flow barriers will shorten the correlation distance, and the absence of barriers will result in a larger average distance of correlation. Variography provides an objective way of evaluating the average distance over which groundwaterelevation measurements may be used to make an estimate of groundwater elevation at another, non-measured location, although the results are heavily dependent on having data available throughout the defined structural region.

The CPRAS was divided by geographic or structural regions on the basis of significantly different variography to improve the estimates of groundwater elevation developed using the kriging analysis. The structural regions used for analysis during this study were modified from Reidel and others (2002) and initially included the Yakima Fold Belt, Palouse Slope, Blue Mountains, and Clearwater Embayment. The extent of these structural regions (pl. 1) was modified on the basis of recent modeling of the extent and thickness of the hydrogeologic units and the geologic structures that form geologic compartments that may influence groundwater levels (E.R. Burns, U.S. Geological Survey, written commun., 2009). The Blue Mountains and Clearwater Embayment structural regions were subsequently eliminated from the analysis because few of the spring 2009 groundwater-level measurements were within these regions. The arc-shaped Yakima Fold Belt is generally composed of long east-west trending valleys separated by fold-fault pairs defining the valley ridgetops (E.R. Burns, U.S. Geological Survey, written commun., 2009). Compared to the Yakima Fold Belt, the Palouse Slope is less deformed, with relatively few faults and less intense folding. On the basis of the significant difference in variography between the Palouse Slope and Yakima Fold Belt, whenever data from a specific hydrogeologic unit were sufficiently dense in each of these structural regions, water-level data within the regions were kriged separately.

Kriging was used for interpolation of the groundwater-level residuals using a lateral grid size of $1,000 \mathrm{ft}$. Kriging is based on a geostatistical theory predicated on the observation that values of spatially distributed data commonly are correlated — values at nearby locations are more highly correlated than values at distant locations (Alley, 1993, p. 87). Parameters for the kriging analysis were selected on the basis of the variography analysis and used to interpolate groundwater levels for each hydrogeologic unit by structural region. The regional trend, estimated using LOESS, and the kriged residuals, representing the configuration of the groundwater surface without the regional influence, were subsequently added together to produce the generalized groundwater-elevation maps for each hydrogeologic unit. 
The estimated groundwater-elevation surfaces for each basalt hydrogeologic unit were compared to land-surface elevation to identify areas where artesian conditions (potential groundwater elevations greater than land-surface elevation) were indicated. Artesian conditions are common in selected areas within the CPRAS; however, the interpolated groundwater surface indicated that artesian conditions were in some areas where no data are available to support their presence, or that the magnitudes of the predicted artesian levels were deemed unreasonable. A small number of such areas occur along the edges of each hydrogeologic unit, where few data exist to constrain the interpolation or in topographical depressions or incised canyons where land-surface elevation decreases rapidly and no data are available for areas within the depression or along the canyon to guide the interpolation. In these situations, the interpolated groundwater elevations were modified such that the mapped groundwater elevations would not exceed the maximum artesian levels observed within each unit. The maximum artesian levels are 50, 225, and $300 \mathrm{ft}$ above land-surface for the Saddle Mountains, Wanapum, and Grande Ronde, respectively.

The estimated groundwater-elevation surfaces for each basalt hydrogeologic unit also were compared to surfaces representing the estimated unit-top elevations from a three-dimensional hydrogeologic framework model (E.R. Burns, U.S. Geological Survey, written commun., 2009) to identify potentially unsaturated areas. On the basis of these comparisons, several areas within the Saddle Mountains and Wanapum Units may be unsaturated. These areas generally are associated with higher land-surface elevations where depths to water are greater and unit thicknesses are thinner. Because of the uncertainty associated with the estimates of the groundwater and unit-top elevations, these areas are retained on the groundwater-elevation maps.

\section{Development of Groundwater-Level Change Maps}

Groundwater levels measured during spring 1984 and spring 2009 were compared for 470 wells to evaluate water-level changes for each of the hydrogeologic units and to construct groundwater-level change maps. The annualized rates of water-level change for the 25-year period between measurements were calculated for each well. This average rate of change based on only two measurements represents a long-term net change in water levels; the sign and rate of change in any particular year could be different and may not be representative of recent trends in water-level changes. The groundwater-level changes presented are for wells at specific locations and may not be representative of conditions throughout the CPRAS.

\section{Changes in Groundwater Conditions and Groundwater Levels}

The accuracy of the groundwater-elevation maps depends on various factors pertaining to the quality, quantity, and spatial distribution of the data, the method of interpolation, and the hydrogeologic properties and stresses within the aquifers. Therefore, the maps of groundwater elevation are approximations whose accuracy is limited by the availability of data. Data density is insufficient to support their use for local or site-specific purposes. These maps are intended to provide a regional overview of groundwater conditions in the CPRAS during spring 2009.

\section{Groundwater Configuration}

The configurations of the groundwater-elevation surface in the Saddle Mountains, Wanapum, and Grande Ronde units during spring 2009 are shown in plates 3, 4, and 5. The generalized groundwater-level maps provide a means to estimate regional-scale groundwater flow direction in that groundwater moves from areas of high to low water-level elevations. However, the groundwater flow system is three-dimensional and consists of vertical and horizontal components of flow that may change with depth in the flow system forming complex flow paths. The overall direction of groundwater flow for each of the basalt units is toward the major groundwater discharge areas, consisting primarily of parts of the Columbia River but also including parts of the Snake and Yakima Rivers. Data density was insufficient to quantify the local directions of groundwater flow, such as in structural basins embedded within the Yakima Fold Belt, although where units occur at or near land surface, groundwater flow generally is expected to be toward streams and rivers that occupy the lowest points in the CPRAS and to follow surface drainage patterns. Additionally, groundwater withdrawals from major pumping centers or widespread recharge from irrigation or canals may produce local to regional variations that may not be reflected in the maps.

Configuration of the groundwater-elevation surfaces for the three basalt units generally compare well with groundwater-elevation surface maps constructed for the three basalt units by Whiteman (1986) on the basis of water levels from spring 1984. The maps by Whiteman (1986) exhibit greater detail because they incorporate a more comprehensive set of data consisting of a larger set of wells and a variety of ancillary data including water levels from years other than 1984, surface-water features, and land-surface topography. The areas where groundwater elevations from 1984 (Whiteman, 1986) and those from 2009 differ (where sufficient data were available for both dates) are most often associated with groundwater-level declines due to pumping since 1984 (see section titled "Water-Level Changes"). 
The groundwater-surface configuration for the Saddle Mountains unit is similar to that of land surface (pl. 3). The highest groundwater elevations exceed 2,000 ft are in eastern Klickitat County, Washington, where the highest land-surface elevations occur within the extent of the unit. The lowest groundwater elevations below $500 \mathrm{ft}$ are in two low-lying areas along the Columbia River, along the border between Franklin and Benton Counties, Washington, and near the junction of Benton County and Morrow and Umatilla Counties, Oregon. However, due to the distribution of available data it is difficult to ascertain the overall directions of groundwater flow in the Saddle Mountains unit with much certainty, with the exception of flow that occurs southeastward along the axes of some valleys in the Yakima Fold Belt. A detailed groundwater elevation and flow direction map constructed for the Saddle Mountains unit (as well as the Wanapum, Grande Ronde, and Overburden units) in the Yakima River basin using water-level data from 2001 is presented in Vaccaro and others (2009).

The groundwater-surface configuration for the Wanapum unit is roughly a circular depression centered southwest of Pasco, Washington, with a slight northeast to southwest elongation and a probable outlet that follows the Columbia River to the west (pl. 4). With few exceptions, the highest groundwater elevations exceeding 2,000 ft occur along the eastern and northeastern extents of the unit. The groundwater-elevation surface generally slopes concentrically inward toward the Columbia and Snake Rivers, reaching minimum elevations of less than $400 \mathrm{ft}$ from the northern end of Benton County extending southeastward to Pasco, Washington, and then extending southwestward to the northeast corner of Gilliam County, Oregon. The general directions of groundwater flow are southwestward from the margin of the Palouse Slope radially towards the Columbia River in the vicinity of Pasco, northward from the Oregon side to the Columbia River, and southeastward along the axes of valleys in the Yakima Fold Belt toward the Yakima or Columbia Rivers.

The configuration of the groundwater surface for the Grande Ronde unit is generally trough shaped, elongated from northeast to southwest in the Pasco, Washington, area and then along a more east-west trend along the Columbia River downstream of Pasco (pl. 5). The highest groundwater elevations occur along the southern, northwestern, and eastern extents of the unit with elevations exceeding 2,000 ft. With few exceptions, the groundwater-elevation surface slopes concentrically inward toward the Columbia and Snake Rivers, reaching minimum elevations of less than $200 \mathrm{ft}$ along the Columbia River between The Dalles, Oregon, and Pasco, Washington. However, data from the central and deepest part of the Grande Ronde unit are sparse or nonexistent leading to high uncertainty in this area. The general directions of groundwater flow are similar to those for the Wanapum unit, with overall directions of flow moving radially from the margins of the unit toward the center of the CPRAS or the Columbia River.
The variography analysis indicated that the maximum range or distance that the groundwater level at a location in the Saddle Mountains unit (that is primarily within the Yakima Fold Belt) could be correlated with the level in another location is about $40 \mathrm{mi}$ along a northwest-southeast direction, but only about $13 \mathrm{mi}$ along a northeast-southwest direction. This difference in range by direction is because the correlation is determined not only by the distance between observations, but also by the direction from one observation to another. For example, water levels in wells along valleys are similar for much greater distances than across valleys, over ridges, and into adjacent valleys. This phenomenon is known as geometric anisotropy and may be explained by the presence of hydraulic barriers (such as those imposed by the faulted ridge tops in the Yakima Fold Belt) or by differences in stresses with direction (such as recharge from precipitation, irrigation, and canals, or discharge due to pumping).

The area of the Wanapum unit primarily extends across the Yakima Fold Belt and Palouse Slope structural regions. The interpolation of groundwater levels was performed separately for each region and then combined to create a map of groundwater levels. Analyses of the Yakima Fold Belt observations yielded a low geometric anisotropy, with a range of about $13 \mathrm{mi}$ along a northwest-southeast direction and $11 \mathrm{mi}$ along a northeast-southwest direction. The Palouse Slope data showed no anisotropy and a range of about $36 \mathrm{mi}$.

The extent of the Grande Ronde unit includes large parts of the Yakima Fold Belt and Palouse Slope structural regions. Variography indicated that groundwater-level correlations within these two regions are substantially different. Within the Yakima Fold Belt, correlations extend about $38 \mathrm{mi}$ along a northeast-southwest direction, with a slight anisotropy, resulting in correlations extending about $32 \mathrm{mi}$ in a northwest-southeast direction. Within the Palouse Slope, the range is about $61 \mathrm{mi}$ in a north-south direction, with a slight anisotropy indicating a range of about $51 \mathrm{mi}$ in an east-west direction.

Overall, the variography analysis was consistent with previously known groundwater flow features in the study area. The generally short ranges in the Yakima Fold Belt structural region indicate that the geologic complexity due to the large number of folds and faults contributes to compartmentalization of the groundwater flow system. The long ranges in the Palouse Slope result from the fewer number of faults and folds and indicate that the groundwater flow system is more continuous in this much less deformed structural region. The orientation of the greatest correlation of groundwater levels for the Saddle Mountains and Wanapum units within the Yakima Fold Belt is consistent with the dip of the valleys for which sufficient data are available. However, the sparse clusters of data relative to geological structures affect the results presented. As a result, the data are supportive and consistent with the geologic model, but the unqualified use of the parameters described above is not recommended when making predictions of groundwater elevations. 
Vertical head differences, calculated as the difference in groundwater elevations between an upper and lower hydrogeologic unit, give an indication of the magnitude and direction of vertical gradients that may influence the vertical component of flow. Accurate head differences depend on the availability of wells that are open to individual hydrogeologic units and are in close proximity (ideally within the same drill hole if properly constructed). Because of the limited availability of this type of data for the three basalt units, only generalized vertical head differences that were calculated by subtracting the estimated water-level surface from one unit from the estimated water-level surface from the underlying unit are discussed. Vertical head differences between the Saddle Mountains and Wanapum units indicate that downward gradients may exist in the Saddle Mountains unit in many of the upper elevation areas. Upward gradients may be in several low-lying areas, including along much of the length of the Columbia River and in some valleys of eastern Yakima County, Washington. Vertical head differences between the Wanapum and Grande Ronde units show no clear spatial patterns possibly as a result of limited data, pumping within either unit, or vertical compartmentalization that may be limiting vertical flow between the units (Porcello and others, 2009).

The depth to water in the basalt units was estimated from the groundwater-elevation maps by subtracting the groundwater elevation from the land-surface elevation (maps of these calculated estimates are not shown). All three basalt units have a modest to strong correlation of depth to water with land-surface elevation, especially where the units are present at the surface. The correlation is strongest for the Saddle Mountains unit. Depth to water was generally shallowest in low-lying or deeply incised valleys and deepest in the higher land-surface elevation and mountainous areas.

\section{Water-Level Changes}

Small to moderate net groundwater-level declines between 1984 and 2009 were measured in most wells, although large declines greater than $100 \mathrm{ft}$ and as great as $300 \mathrm{ft}$ and essentially unchanged groundwater levels were not uncommon (pls. 6, 7, 8, and 9; table 1). Of the wells measured in 1984 and 2009, water levels declined in 83 percent of the wells and declines greater than $25 \mathrm{ft}$ were measured in 29 percent of all wells. The magnitude of changes in water level depends on the change in storage within the aquifer, which is a function of the quantity of recharge or discharge added or removed from the aquifer and the storage properties of the aquifer.

The smallest change in groundwater levels in terms of maximum decline, maximum rise, and mean change was measured in the Overburden unit (pl. 6; table 1). The frequency distribution of water-level changes indicates that
Table 1. Change in groundwater levels in wells in the Columbia Plateau Regional Aquifer System, Washington, Oregon, and Idaho, from spring 1984 to spring 2009.

[Negative values indicate a decline in groundwater levels]

\begin{tabular}{lcccc}
\hline & \multicolumn{5}{c}{ Hydrogeologic unit } \\
\cline { 2 - 5 } & Overburden & $\begin{array}{c}\text { Saddle } \\
\text { Mountains }\end{array}$ & Wanapum & $\begin{array}{c}\text { Grande } \\
\text { Ronde }\end{array}$ \\
\hline Number of wells & 197 & 50 & 87 & 136 \\
\hline \multicolumn{5}{c}{ Change in groundwater level, in feet } \\
\hline $\begin{array}{l}\text { Maximum decline } \\
\text { Maximum rise }\end{array}$ & -147 & -244 & -249 & -298 \\
$\begin{array}{l}\text { Mean change } \\
\text { Annualized change in groundwater level, in feet per year }\end{array}$ & 44 & 77 & 94 & 90 \\
\hline $\begin{array}{l}\text { Maximum rate of } \\
\text { decline }\end{array}$ & -5.9 & -9.8 & -9.9 & -11.9 \\
$\begin{array}{l}\text { Maximum rate of } \\
\text { rise }\end{array}$ & 1.8 & 3.1 & 3.8 & 3.6 \\
\begin{tabular}{l} 
Mean rate of change \\
\hline
\end{tabular} & -.3 & -.5 & -1.3 & -2.0 \\
\hline
\end{tabular}

little change in water levels occurred in most areas, although some areas showed a tendency toward small groundwater declines and a few areas exhibited small groundwater rises. Of the wells measured in spring 1984 and spring 2009, water levels declined in 87 percent of the wells, although declines greater than $25 \mathrm{ft}$ were measured in only 8 percent of the wells. Most of the wells measured in the Overburden unit as part of this analysis are located within the Hanford Site operated by the Department of Energy in northern Benton County, Washington. Water levels in the area of the Hanford Site showed little change except for the central or northwestern areas, which show small to moderate water level declines. These declines can be largely attributed to the substantial decrease in liquid effluent disposal at the Hanford Site during the 1990s (Pacific Northwest National Laboratory, 2009).

Most groundwater levels measured in the Saddle Mountains unit showed small declines, although large declines or small to moderate rises were indicated in some areas (pl. 7; table 1). Water levels declined in 68 percent of the wells and declines were greater than 25 percent in 16 percent of the wells. The magnitudes of the water-level changes were low relative to the other basalt hydrogeologic units. Spatial trends in water-level changes in the Saddle Mountains unit were difficult to discern due to the distribution of the data. An area of small groundwater-level declines was identified in the central area of the Hanford Site. Groundwater declines also were identified in the Yakima River basin. Small water-level rises were measured in the area along the northeast side of the Columbia River within the Palouse Slope. 
Groundwater levels in the Wanapum unit mostly showed small or moderate declines, with large declines (greater than $100 \mathrm{ft}$ ) in a few areas (pl. 8; table 1). Between 1984 and 2009, water levels declined in 78 percent of the wells measured and declines greater than $25 \mathrm{ft}$ were measured in 38 percent of the wells. Wells within the Yakima Fold Belt structural region generally had larger groundwater declines relative to the Palouse Slope. This may be the combined result of pumping and the increased compartmentalization of the groundwater system by geologic structures present in the Yakima Fold Belt. The largest concentration of declines was in the Yakima River basin, which corresponds to areas of heavy pumping within the Wanapum unit (Whiteman and others, 1994).

Groundwater levels changed in the Grande Ronde unit more than water levels in the other units in terms of maximum decline and mean change (pl. 9; table 1). Moderate declines in water levels were measured in most areas, with declines greater than $100 \mathrm{ft}$ and some greater than $200 \mathrm{ft}$. Water levels declined in 87 percent of the wells, and declines greater than $25 \mathrm{ft}$ were measured in 60 percent of the wells. Substantial rises in groundwater levels were measured in few wells. Groundwater declines were present in the Grande Ronde unit throughout much of the area where wells were measured. The largest concentrations of declines were in the central northern part of the study area that extends from western Lincoln County, Washington, southward into eastern Grant and southwestern Adams Counties, Washington. Large concentrations of declines also were measured in the part of the Umatilla River basin in northeast Morrow and western Umatilla Counties, Oregon, and in the Pullman, Washington, and Moscow, Idaho, area. These concentrations of declines in water levels correspond with areas of heavy pumping within the Grande Ronde unit (Whiteman and others, 1994).

This report provides a regional assessment of groundwater levels during spring 2009 based on an inventory of 1,752 wells in the Columbia Plateau of Washington, Oregon, and Idaho. Data included in the report are from field investigations and a compilation of published and unpublished well data from many agencies. Water-level change maps are presented for the Overburden, Saddle Mountains, Wanapum, and Grande Ronde units and indicate trends toward waterlevel declines in many areas since 1984 . The distribution of wells monitored in spring of 2009 provide information on where additional monitoring would better define the response of the groundwater system to stresses such as pumping, irrigation, and climate.

\section{Acknowledgments}

The authors thank the many people that contributed their time and knowledge to help complete this study. We are grateful to the many well owners who have permitted access to their wells, well drillers who have diligently recorded and reported their findings, and the many people and agencies that collect, analyze, maintain, or disseminate the scientific data needed for studies of groundwater systems. The following agencies are noted for their special assistance with the collection of data used in this study: U.S. Department of Energy, Oregon Water Resources Department, Confederated Tribes of the Umatilla Indian Reservation, Washington Department of Ecology, South Columbia Basin Irrigation District, Walla Walla Basin Watershed Council, Palouse Basin Aquifer Committee, East Columbia Basin Irrigation District, Bureau of Reclamation, Franklin Conservation District, and the Columbia Basin Ground Water Management Area. USGS employees whose efforts contributed to the study include Erick Burns, Matt Ely, and Sue Kahle, whose statistical, modeling, and geologic expertise facilitated the interpretation of the data; Gregory Justin, Karen Payne, Danial Polette, Kevin Knutson, Rachel Peavler, Keith Hein, Peter Elliott, Tessa Harden, Annette Campbell, and Benjamin Johnson (volunteer) who assisted in the collection of field data to supplement the knowledge of the groundwater system; Leonard Orzol, Tiffany Jacklin, and Elisabeth Fasser whose skills greatly simplified access to existing data; David Morgan and Richard Dinicola for their guidance and support, and the many other USGS employees whose everyday efforts go to support this and many other studies.

\section{References Cited}

Alley, W.M., 1993, Geostatistical models, in Alley, W.M., ed., Regional ground-water quality: New York, Van Nostrand Reinhold, p. 87-108.

Bauer, H.H., and Hansen, A.J., 2000, Hydrology of the Columbia Plateau regional aquifer system, Washington, Oregon, and Idaho: U.S. Geological Survey WaterResources Investigations Report 96-4106, 61 p. (Also available at http://pubs.er.usgs.gov/usgspubs/wri/ wri964106.) 
Bossong, C.R., Karlinger, M.R., Troutman, B.M., and Vecchia, A.V., 1999, Overview and technical and practical aspects for use of geostatistics in hazardous-, toxic-, and radioactive-waste-site investigations: U.S. Geological Survey Water-Resources Investigations Report 98-4145, 70 p. (Also available at http://pubs.er.usgs.gov/usgspubs/ wri/wri984145.)

Davis, J.C., 2002, Statistics and data analysis in geology (3d ed.): New York, John Wiley and Sons, 638 p.

Drost, B.W., Whiteman, K.J., and Gonthier, J.B., 1990, Geologic framework of the Columbia Plateau Aquifer System, Washington, Oregon, and Idaho: U.S. Geological Survey Water-Resources Investigations Report 87-4238, 10 p., 10 sheets. (Also available at http://pubs.er.usgs.gov/ usgspubs/wri/wri874238.)

Kahle, S.C., Olsen, T.D., and Morgan, D.S., 2009, Geologic setting and hydrogeologic units of the Columbia Plateau Regional Aquifer System, Washington, Oregon, and Idaho: U.S. Geological Survey Scientific Investigations Map 3088, 1 sheet. (Also available at http://pubs.er.usgs.gov/usgspubs/ $\underline{\operatorname{sim} / \operatorname{sim} 3088}$.)

Newcomb, R.C., 1959, Some preliminary notes on ground water in the Columbia River Basalt: Northwest Science, v. 33, no. 1, p. 1-18, accessed September 3, 2009, at http:// www.vetmed.wsu.edu/org NWS/NWSci\%20journal\%20 articles/1950-1959/1959\%20vol\%2033/33-1/v33\%20 p1\%20Newcomb.PDF.

Pacific Northwest National Laboratory, 2009, Hanford Site environmental report for calendar year 2008: prepared for U.S. Department of Energy under Contract DE-AC0576RL01830; available from the National Technical Information Service, U.S. Department of Commerce, Springfield, Va., variously paged, accessed September 3, 2009, at http://hanford-site.pnl.gov/envreport/2008/pnnl18427.pdf.

Porcello, J.J., Tolan, T.L., and Lindsey, K.A., 2009, Groundwater level declines in the Columbia River Basalt Group and their relationship to mechanisms for groundwater recharge-A conceptual groundwater system model, Columbia Basin Ground Water Management Area of Adams, Franklin, Grant, and Lincoln Counties: Othello, Washington: prepared by the Columbia Basin Ground Water Management Area of Adams, Franklin, Grant, and Lincoln Counties, June, 2009, 175 p., accessed September 3, 2009, at http://www.cbgwma.org/pdf/GWMA Groundwater\%20 Level\%20Declines \%20TEXT June\%202009.pdf.
Reidel, S.P., Johnson, V.G., and Spane, F.A., 2002, Natural gas storage in basalt aquifers of the Columbia Basin, Pacific Northwest USA - A guide to site characterization: Pacific Northwest National Laboratory, Richland, Washington, variously paginated, accessed August 22, 2009, at http:// www.pnl.gov/main/publications/external/technical reports/ PNNL-13962.pdf.

Tolan, T.L., Reidel, S.P., Beeson, M.H., Anderson, J.L., Fecht, K.R., and Swanson, D.A., 1989, Revisions to the estimates of the areal extent and volume of the Columbia River Basalt Group, in Reidel, S.P., and Hooper, P.R., eds., Volcanism and tectonism in the Columbia River flood-basalt province: Geological Society of America Special Paper 239, p. 1-20.

U.S. Geological Survey, 1999, National Elevation Dataset: U.S. Geological Survey Fact Sheet 148-99, 2 p. (Also available at http://erg.usgs.gov/isb/pubs/factsheets/fs14899. $\underline{\text { html.) }}$

U.S. Geological Survey, 2008, Ground-Water Availability Assessment for the Columbia Plateau Regional Aquifer System, Washington, Oregon, and Idaho: U.S. Geological Survey Fact Sheet 2008-3086, 2 p. (Also available at http:// pubs.er.usgs.gov/usgspubs/fs/fs20083086.)

Vaccaro, J.J., 1999, Summary of the Columbia Plateau Regional Aquifer-System Analysis, Washington, Oregon, and Idaho: U.S. Geological Survey Professional Paper 1413-A, 51 p. (Also available at http://pubs.er.usgs.gov/ usgspubs/pp/pp1413A.)

Vaccaro, J.J., Jones, M.A., Ely, D.M., Keys, M.E., Olsen, T.D., Welch, W.B., and Cox, S.E., 2009, Hydrogeologic framework of the Yakima River basin aquifer system, Washington: U.S. Geological Survey Scientific Investigations Report 2009-5152, 106 p. (Also available at http://pubs.er.usgs.gov/usgspubs/sir/sir20095152.)

Whiteman, K.J., 1986, Ground-water levels in three basalt hydrologic units underlying the Columbia Plateau, Washington and Oregon, spring 1984: U.S. Geological Survey Water-Resources Investigations Report 86-4046, 4 sheets. (Also available at http://pubs.er.usgs.gov/ usgspubs/wri/wri864046.)

Whiteman, K.J., Vaccaro, J.J., Gonthier, J.B., and Bauer, H.H., 1994, Hydrogeologic framework and geochemistry of the Columbia Plateau regional aquifer system: U.S. Geological Survey Professional Paper 1413-B, 73 p. (Also available at http://pubs.er.usgs.gov/usgspubs/pp/pp1413B.) 


\section{Appendix A. Records of Selected Wells in the Columbia Plateau Regional Aquifer System}

The appendix contains limited information for selected wells including identifier, location, elevation, construction, water levels, and hydrogeologic unit and is available in a Microsoft Excel spreadsheet at http://pubs.usgs.gov/sir/2010/5040/. 
12 Groundwater Conditions 2009, and Changes in Groundwater Levels 1984-2009, Columbia Plateau Regional Aquifer System

This page intentionally left blank. 
Publishing support provided by the U.S. Geological Survey

Publishing Network, Tacoma Publishing Service Center

For more information concerning the research in this report, contact the Director, Oregon Water Science Center

U.S. Geological Survey

2130 SW 5th Avenue

Portland, Oregon 97201

http://or.water.usgs.gov 
